\title{
Multiple PCR analyses on trace amounts of DNA extracted from fresh and paraffin wax embedded tissues after random hexamer primer PCR amplification
}

\author{
H Z Peng, P G Isaacson, T C Diss, L X Pan
}

\begin{abstract}
Aim-To establish a simple and reliable polymerase chain reaction (PCR) methodology for random amplification of whole genomic DNA from limited histopathological samples.

Methods-Trace amounts of genomic DNA extracted from fresh tissue and individual lymphoid follicles microdissected from archival paraffin wax tissue sections were amplified using a twophase PCR protocol with random hexamers as primers (RP-PCR). The randomly amplified DNA samples were used as templates for specific PCR amplifications. To check the fidelity of the RPPCR, products of the specific PCR amplifications were further analysed by single stranded conformation polymorphism (SSCP) or sequencing.

Results-Using a minute fraction of RPPCR template pool, multiple PCR analyses, including those for $\beta$ globin gene, p53 gene (exon 5-6, exon 7, exon 8-9 and exon 7-9), and rearranged immunoglobulin heavy chain gene fragments (VH framework 3 to JH and VH framework 2 to JH) were successfully performed. No artefactual mutations were identified in the products of these specific PCR reactions by SSCP or sequencing when compared with the products from the original DNA. Conclusion-This method is simple and reliable, and permits multiple genetic analyses when only a limited amount of tissue is available.
\end{abstract}

(F Clin Pathol 1994;47:605-608)

The high sensitivity of the polymerase chain reaction (PCR) has facilitated the performance of genetic analysis on scanty pathological samples, such as fine needle aspirates, single tissue sections, or cell populations microdissected from archival tissue sections. In most of these cases there is insufficient DNA for more than a few amplifications. To characterise the genotype of a cell population in a pathological lesion it is often desirable to perform repeated or multiple PCR analyses. Tiny DNA samples are therefore inadequate for this purpose. Random amplification of total DNA in minute samples into expanded template pools for subsequent specific PCR may overcome this limitation.
Amplification of total genomic DNA has been achieved using several methods, such as those using random 15 mer primers, ${ }^{1}$ degenerate primers, ${ }^{2}$ and linker adaptor ligation. ${ }^{3}$ It has also been used in the cloning of microdissected chromosomes, single cell genotyping, and generating ancient DNA libraries. In this study we used a mixture of random hexamers that is readily available because it is commonly used for DNA probe labelling, as primers for PCR amplification of whole genomic DNA. Our aim was to establish a simple and reliable methodology for random PCR amplification of minute amounts of DNA from histological samples.

\section{Methods}

DNA SAMPLE PREPARATION

High molecular weight DNA was extracted from snap-frozen tissue of a low grade mucosa associated lymphoid tissue (MALT) B cell lymphoma using a standard method. Four individual $B$ cell follicles which had been colonised by the tumour cells ${ }^{4}$ were microdissected from a paraffin wax processed haematoxylin and eosin stained section of the same case, as described before. ${ }^{5}$ Each microdissected follicle was digested in $10 \mu \mathrm{l}$ of a solution containing $200 \mu \mathrm{g} / \mathrm{ml}$ proteinase $\mathrm{K}, 10$ $\mathrm{mM}$ TRIS-HCl (pH8.3), $50 \mathrm{mM} \mathrm{KCl}, 0.1 \%$ Triton-X100 for three days at $37^{\circ} \mathrm{C}$. DNA samples from cell lines containing mutated p53 exon 5, 6 (HUT78), 7 (BL37), 8 and 9 $(B L 113)^{6}$ were used as positive controls for single strand conformation polymorphism analysis (SSCP).

RANDOM HEXAMER PRIMER PCR

AMPLIFICATION (RP-PCR)

RP-PCR was performed in two phases. Phase I reactions were run in a $10 \mu$ l solution containing 0.025 units of AmpliTaq polymerase (Perkin Elmer Cetus UK), $10 \mathrm{mM}$ TRIS (pH8.3), $50 \mathrm{mM} \mathrm{KCl}, 1 \mathrm{mM} \mathrm{MgCl} 2,0.001 \%$ gelatin, $0.02 \mathrm{mM}$ of each dNTP, $10 \mu \mathrm{M}$ of random hexamers (Boehringer, Germany) and $4 \mu \mathrm{l}$ of the $10 \mu \mathrm{l}$ digest of each microdissected follicle or appropriate amounts (including $40 \mathrm{ng}, 4 \mathrm{ng}, 400 \mathrm{pg}, 40 \mathrm{pg}$ and $4 \mathrm{pg}$ ) of high molecular weight DNA. After initial denaturation of DNA at $95^{\circ} \mathrm{C}$ for five minutes, 10 cycles of one minute at $95^{\circ} \mathrm{C}$, one minute at $37^{\circ} \mathrm{C}$, and five minutes at $50^{\circ} \mathrm{C}$ were carried out on a thermal cycler (Hybaid UK). At the end of cycle 10 , a $40 \mu$ l solution 
containing 0.5 units Amplitaq, $1.5 \mathrm{mM}$ $\mathrm{MgCl}_{2}, 0.2 \mathrm{mM}$ of each $\mathrm{dNTP}$, and the same concentrations of other reagents (without additional template DNA) as in phase I was added. Forty phase II cycles of one minute at $95^{\circ} \mathrm{C}$, one minute at $55^{\circ} \mathrm{C}$, and two minutes at $72^{\circ} \mathrm{C}$ were performed. At the end of phase II, a $50 \mu \mathrm{l}$ product pool was generated. To optimise the random primer concentration, PCR amplification for p53 exon 7-9 (840 base pairs) was performed on the RP-PCR pools generated using serial dilutions (1-100 $\mu \mathrm{M})$ of the random primers and $400 \mathrm{pg}$ high molecular weight DNA. The products of the specific PCR were analysed using agarose gel electrophoresis.

\section{MULTIPLE PCR ANALYSES}

Seven different specific PCR analyses $(\beta$ globin gene, p53 gene (exon 5-6, exon 7, exon 8-9 and exon 7-9) and rearranged immunoglobulin (Ig) heavy chain gene fragments $\mathrm{VH}$ framework 3 to $\mathrm{JH}$ and $\mathrm{VH}$ framework 2 to $\mathrm{JH})$ ) were performed on individual RP-PCR product pools generated from the microdissected follicles, and $40 \mathrm{ng}, 4 \mathrm{ng}, 400 \mathrm{pg}, 40$ pg, 4 pg high molecular weight DNA using the primers and conditions, as described before. ${ }^{7-9}$ Each of these specific PCR analyses required $2 \mu \mathrm{l}$ of the $50 \mu \mathrm{l}$ RP-PCR product pool as template. For comparison, the same PCR analyses were also performed on $2 \mu \mathrm{l}$ of $50 \mu \mathrm{l}$ solutions containing $40 \mathrm{ng}, 4 \mathrm{ng}, 400$ $\mathrm{pg}, 40 \mathrm{pg}$ and $4 \mathrm{pg}$ of the same high molecular weight DNA without RP-PCR amplification. Ten microlitres of PCR products were separated by electrophoresis on $2 \%$ or $3 \%$ agarose gels with ethidium bromide added and viewed under ultraviolet light.

\section{PCR-SSCP ANALYSIS}

To examine any introduced sequence changes, the products of the multiple specific PCR reactions generated from one of the RPPCR template pools of the microdissected follicles were analysed by SSCP. The products of the same specific PCR reactions from high molecular weight DNA without RP-PCR amplification were run in parallel.

A minute portion of the specific PCR products ( $1 \mu 1$ of 1 in 100 dilution) was used as a template for a second PCR amplification. This was performed in a $15 \mu$ l volume under the same conditions described above in the presence of $1 \mu \mathrm{Ci}{ }^{32} \mathrm{P}-\mathrm{dCTP}$ (Amersham UK). The product of the second PCR was diluted with 5 to 25 volumes of a solution

Results of multiple PCR on fresh DNA samples before (B) and after (A) RP-PCR

\begin{tabular}{llllllll}
\hline $\begin{array}{l}\text { Multiple } \\
\text { PCR }\end{array}$ & $\begin{array}{l}\text { Size } \\
\text { (base pairs) }\end{array}$ & $\begin{array}{l}1.6 \mathrm{ng} \\
(B)(A)\end{array}$ & $\begin{array}{l}0.16 \mathrm{ng} \\
(B)(A)\end{array}$ & $\begin{array}{l}16 \mathrm{pg} \\
(B)(A)\end{array}$ & $\begin{array}{l}1.6 \mathrm{pg} \\
(B)(A)\end{array}$ & $\begin{array}{l}0.16 \mathrm{pg} \\
(B)(A)\end{array}$ & $\begin{array}{l}\mathrm{H}_{2} \mathrm{O} \\
(B)(A)\end{array}$ \\
\hline Ig FR3 & 105 & $+1+$ & $+1+$ & $+1+$ & $-1+$ & $-1+$ & $-1-$ \\
Ig FR2 & 260 & $+1+$ & $+1+$ & $-1+$ & $-1+$ & $-1-$ & $-1-$ \\
B globin & 250 & $+1+$ & $+1+$ & $+1+$ & $-1+$ & $-1+$ & $-1-$ \\
p53,5-6 & 408 & $+1+$ & $+1+$ & $+1+$ & $-1+$ & $-1+$ & $-1-$ \\
p53,7 & 139 & $+1+$ & $+1+$ & $+1+$ & $-1+$ & $-1+$ & $-1-$ \\
p53,8-9 & 330 & $+1+$ & $+1+$ & $-1+$ & $-1+$ & $-1-$ & $-1-$ \\
p53,7-9 & $\mathbf{8 4 0}$ & $+1+$ & $-1+$ & $-1+$ & $-1-$ & $-1-$ & $-1-$ \\
\hline
\end{tabular}

containing $0 \cdot 1 \%$ sodium dodecyl sulphate and $10 \mathrm{mM}$ EDTA. Five to $10 \mu \mathrm{l}$ of this mixture was further diluted with one volume of a loading solution containing $95 \%$ formamide, 20 $\mathrm{mM}$ EDTA, $0.05 \%$ xylene cyanol and bromphenol blue. The samples were denatured at $90^{\circ} \mathrm{C}$ for three minutes, chilled on ice, and loaded on to $6 \%$ acrylamide gels $(2 \% \mathrm{C})$. The gels were run at 1 watt for 11 to 21 hours at room temperature, cooled by a water jacket. The acrylamide gels were dried on filter paper and exposed to $x$ ray film at $-70^{\circ} \mathrm{C}$ with an intensifying screen for five to 24 hours.

\section{CLONING AND SEQUENCING ANALYSIS}

To analyse further any possible artefactual mutations, products of the Ig gene PCR amplification generated from the above RPPCR template pool and high molecular weight DNA without RP-PCR amplification were cloned and sequenced. The products were run on a $4 \%$ low melting temperature agarose gel. The discrete bands were excised and purified using the Mermaid Kit (Bio 101 Inc, California, USA). The purified fragments were ligated into pBluescript SKII phagemid (Stratagene, La Jolla, California, USA) and the recombinant DNAs were used to transform SURE bacteria (Stratagene). Colonies were screened by PCR amplification for the cloned Ig fragment. Three positive recombinant DNAs from each original PCR reaction with and without RP-PCR amplification were sequenced by the Sanger method using the Sequenase kit (United States Biochemical, Cleveland, Ohio).

\section{Results}

All concentrations of random hexamer primers used were able to generate the 840 base pair fragment of p53 exon 7-9, except 1 $\mu \mathrm{M}$. Ten microlitres was selected as the standard concentration for the primer in all the subsequent RP-PCR reactions.

Among the seven specific PCR reactions performed on RP-PCR template pools generated from the four microdissected follicles, six produced discrete fragments with expected sizes (ranging from 100 to 413 base pairs). The fragment of p53 exon 7-9 (840 base pairs) could not be amplified from any of these pools. The results of the multiple PCR reactions performed on the RP-PCR template pools generated from various amounts of fresh DNA are summarised in the table.

Before RP-PCR amplification the minimum amount of high molecular weight DNA template used for individual PCR reactions ranged from $16 \mathrm{pg}$ ( $2 \mu \mathrm{l}$ from $50 \mu$ l of the 400 pg dilution) to $1.6 \mathrm{ng}$ ( $2 \mu \mathrm{l}$ from $50 \mu \mathrm{l}$ of the $40 \mathrm{ng}$ dilution). After RP-PCR amplification $0.16 \mathrm{pg}$ ( $2 \mu \mathrm{l}$ from $50 \mu \mathrm{l}$ of the $4 \mathrm{pg}$ pool) to $16 \mathrm{pg}$ ( $2 \mu \mathrm{l}$ from $50 \mu \mathrm{l}$ of the $400 \mathrm{pg}$ pool) of fresh DNA was shown to be sufficient for the same PCR analyses. Thus RP-PCR increased the sensitivity of specific $P C R$ reactions by at least 100 times. 


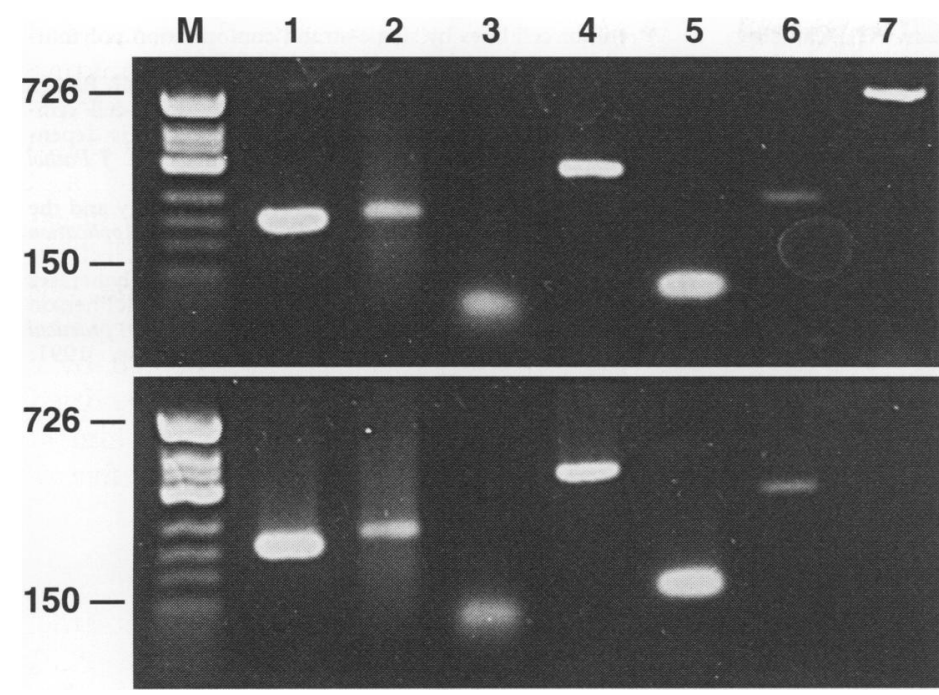

Figure 1 Ethidium bromide stained agarose gel showing products of specific PCR amplifications on RP-PCR template pools. (A) Template pool generated with $400 \mathrm{pg}$ of high molecular weight DNA; (B) template pool generated with DNA prepared from a microdissected lymphoid follicle. Lane $M: \emptyset X /$ Hinf1 molecular weight marker (size in base pairs); lanes 1-7: $\beta$ globin, Ig (Fr2-fH), Ig (Fr3- fH), p53 exon 5-6, p53 exon 7, p53 exon 8-9, p53 exon 7-9.
No difference in mobility was identified on the SSCP gels between the products of the six specific PCR reactions generated from the RP-PCR template pool of the microdissected follicle and the products of the same PCR reactions from the original high molecular weight DNA without RP-PCR amplification (figs 1 and 2).

The sequences of the clones analysed (three from original high molecular weight DNA sample and three from a RP-PCR product pool of a microdissected follicle of the same case) were identical (FR3 primer-ACG TCA TAA TGT AGT AGT AGC ACC CAT TGG AGT AGC AGC TAC CAC CAC CGT AAA CCT CTC GAC-JH region primer).

\section{Discussion}

Using the random hexamers from an oligolabelling kit as primers, we have developed a

\footnotetext{
Figure 2 SSCP analysis of PCR products of $p 53$ gene amplified from $D N A$ templates with and without $R P-P C R$. (A) p53 exon 5-6; (B) p53 exon 7; (C) p53 exon 8-9. Lanes $1-4$ : original DNA;DNA after $R P-P C R$; positive control $D N A$ from cell lines (HUT78 for $p 53$ exon 5-6, BL37 for $p 53$ exon 7 , $B L 113$ for $p 53$ exon 8-9); negative control DNA from placenta.
}

simple method, referred to here as RP-PCR, for amplification of total genomic DNA. As little as $4 \mathrm{pg}$ of DNA from fresh tissue or DNA from a single follicle of an archival paraffin wax section can be readily amplified by this method into a template pool. A minute fraction of this pool contains sufficient DNA for a number of specific PCR analyses.

One major concern about PCR random amplification of trace amounts of DNA is the fidelity of the amplified products. To achieve good fidelity it is critical to minimise errors in the DNA copying process during early PCR cycles, as these errors can be further amplified later. For this reason, we divided our RP-PCR into two phases. In phase I we reduced the amount of Taq polymerase and dNTP to restrict the errors caused by the enzyme ${ }^{10}$ and used a recommended extension temperature at which a good combination of fidelity and efficiency of the enzyme could be obtained. ${ }^{11}$ We also performed the phase I reaction in a small volume to ensure accurate temperature control. In phase II standard PCR conditions were applied to increase yield of the products. Sequencing and SSCP analysis of the specific PCR products confirmed the high fidelity of the RP-PCR.

In titration tests of high molecular weight template DNA RP-PCR increased the sensitivity of specific PCR by over 100 times. Amplification of DNA fragments up to 400 base pairs in archival material and 800 base pairs in fresh tissue extracts could be achieved by standard PCR when RP-PCR products were used as templates. The successful amplification of a number of different gene fragments has also indicated that RP-PCR can generate a representative template pool. These features should meet the requirements for most current PCR analyses.

The main advantage of RP-PCR over other methods, such as the random $15 \mathrm{mer}^{1}$ and linker adaptor methods ${ }^{3}$ for PCR random amplification of genomic DNA, is that the random hexamer primers are inexpensive and readily available. RP-PCR, together with some newly developed techniques, such as microdissection, ${ }^{5}$ should make it feasible to perform multiple genetic analyses on defined cell populations on tissue sections or scanty amounts of pathological material.

This study was supported by the Cancer Research Campaign UK. We thank Dr MQ Du for supplying control cell line DNA and his valuable comments on this paper.

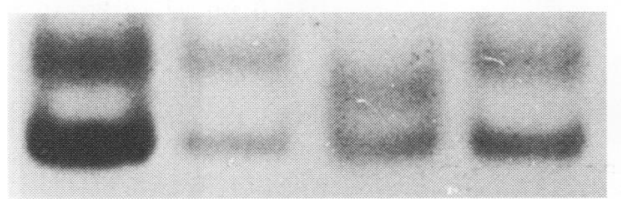

1 Zhang L, Cui X, Schmitt K, Hubert R, Navidi W, Arnheim $\mathrm{N}$. Whole genome amplification from a single cell: implications for genetic analysis. Proc Natl Acad Sci USA 1992;89:5847-51.

2 Telenius $H$, Carter NP, Bebb CE, Nordenskjold $M$, Ponder BA, Tunnacliffe A. Degenerate oligonucleotideprimed PCR: general amplification of target DNA by single degenerate primer. Genomics 1992;13:718-25.

3 Foo I, Salo WL, Aufderheide AC. PCR libraries of ancient DNA using a generalized PCR method. Biotechniques

4 Isaacson PG, Wotherspoon AC, Diss T, Pan LX. Follicular colonization in B-cell lymphoma of mucosaassociated lymphoid tissue. Am $\mathcal{F}$ Surg Pathol 1991;15: associated 
5 Pan LX, Diss TC, Peng HZ, Isaacson PG. Clonality analysis of defined $B$ cell populations in archival tissue sections using microdissection and polymerase chain reaction (PCR). Histopathology 1994;24:323-7.

6 Gaidano G, Ballerini P, Gong JZ, Inghirami G, Neri A Newcomb EW, et al. p53 mutations in human lymphoi malignancies: association with Burkitt lymphoma and chronic lymphocytic leukemia. Proc Natl Acad Sci USA 1991;88:5413-17.

7 Saiki RK, Gelfand DH, Stoffel S, Scharf SJ, Higuchi R, Horn G, et al Primer-directed enzymatic amplification of DNA with a thermostable DNA polymerase. Science 1988;239:487-91.

8 Murakami Y, Hayashi K, Sekiya T. Detection of aberrations of the p53 alleles and the gene transcript in human tumor cell lines by single-strand conformation polymorphism analysis. Cancer Res 1991;51:3356-61.

9 Diss TC Pengi H W Wer Res 1991,51:3356-61. PG Pan Detection of monoclonality in low-grade B-cell lymphomas using the polymerase chain reaction is dependent on primer selection and lymphoma type. F Pathol 1993;169:291-5.

10 Eckert KA, Kunkel TA. DNA polymerase fidelity and the polymerase chain reaction. PCR Methods Application 1991;1:17-24.

11 Eckert KA, Kunkel TA. The fidelity of DNA polymerase used in the polymerase chain reactions. In: McPherson MJ, Quirke P, Taylor GR eds. PCR, a practical approach. Oxford: Oxford University Press, 1991: approach. 